\title{
THE INSURANCE OF LIABILITY AS AN ATTEMPT OF RISK TRANSFERING OVER THE LOSS CAUSED BY NOTARY PULIC AND LAND DEED OFFICIALS
}

\author{
Ghansham Anand ; Agus Yudha Hernoko² ${ }^{2}$ Mokhamad Khoirul Huda ${ }^{3}$ \\ ${ }^{1,2}$ Faculty of Law, Airlangga University, Surabaya \\ ${ }^{3}$ Faculty of Law, Hang Tuah University, Surabaya \\ E-mail: emka.huda@hangtuah.ac.id
}

\begin{abstract}
This study primarily aimed to identify the type of insurance of liabilities as an attempt of risk transferring over the loss caused by the notary public and land deed officials. The method of this study was juridical-normative. The result showed that the notary public and land deed officials (PPAT) were both public officials authorized to establish an authentic deed due to clients' requests. Any violation or negligence by Notary public and land deed officials that was out of the track of legal law might lead the clients into a disadvantageous situation. Such violation or negligence made the established deed null and void, void-able, or even turned into an private deed. This brought an effect to the client as the injured party, and thus, they might file a lawsuit in case of suing for compensation, indemnification, and interest through court proceeding. Therefore, it needed an agency of risk-transfering in the form of insurance. The insurance of professional liability is a product of public insurance taking-over a risk that is supposed to be charged by the Notary Public and Land Deed Officials. The object of this insurance refers to the insurer's obligation to pay compensation over particular loss the client has suffered and other expenses due to the risk.
\end{abstract}

Keywords: Liability, Risk, Professional Insurance, Notary Public and Land Deed Officials, Insurer, Insured.

\section{A. INTRODUCTION}

Article 2 of Act Number 30 of 2004 on Notarial Function (known as UUJN) mentions that notaries are appointed by the Minster of Law and Human Rights. Drawing on Lumban (1983), the appointment of notaries is not for personal interest of the notary self; rather, it is for public interest. Thus, the presence of notarial agencies in Indonesia is always controlled by government and juridical institution. It aims to keep the notary on their track in implementing their professional functions to satisfy any conditions that relate to their profession as notary for the sake of public interest. Another intention of controlling the notary public is to serve people with evidence needs in the form of authentic deeds as their requests on the notary public (Lotulung, 1993). 
The scope of notarial function involves establishing evidence at clients' request for particular legal action, and the evidence is in civil/private law level. The notary establishes a deed as their clients' requests. They may not establish any deed without any request from any party. The notary establishes a deed based on the evidence or the explanation or statements that the clients have presented, explained, or expressed to the notary. Subsequently, the notary may frame the evidence in literal, formal, and substantive way within a notarial deed, by keeping standing on the legal regulation related to the procedures of deed establishment, and the legal regulation that deals with a legal action is mentioned on the deed. In practical field, however, the notary is often defined as defendant by another party, since the notary's legal action seems to bring the party into disadvantageous situation.

Misimplementation of profession is due to whether the lack of knowledge (onvoldoende kennis), experience (onvoldoende ervaring), or the lack of definition (Nico, 2003). Similarly, the notary's fault in implementing their authority and task is sometimes due to the lack of their knowledge on issues the clients have requested for, both from legal or other aspects (Thamrin, 2011).

The notary's violation or fault in implementing their task and authority which is inconsistent with the regulation may cause disadvantages toward the clients and/or other parties. Such fault may make the deeds they established null and void (van rechtswege nietig), and voidable (vernietigbaar) or may only have evidence power as a private deed (onderhands acte). Thus, it may make the notary responsible to bear the compensation. The injured party of such violation may file their claim for compensation or indemnification of expenses and interest to the pertinent notary pulic through the court. Article 91A of Act Number 2 of 2014 about the amendment of Act Number 30 of 2004 about Notarial Function (later known as UUJN amendment) sets the procedural rules of providing sanctions as mentioned in Article 7 subsection (2), Article 16 subsection (11) and (13), Article 17 subsection (2), Article 19 subsection (4), Article 32 subsection (4), Article 37 subsection (2), Article 54 subsection (2), and Article 65A will set the rule of Minister. As to 
imposition of sanction in UUJN amendment, it is divided into 2 (two) subdivision, including the imposition of sanction toward the notary and toward the notarial deeds.

Sanction toward the notary is set under Article 7 subsection (2), Article 16 subsection (11) and (13), Article 17 subsection (2), Article 19 subsection (4), Article 32 subsection (4), Article 37 subsection (2), Article 54 subsection (2), and Article 65A. The sanction is in the form of: a). written warning; b). lay-off; c). honorable discharge; or d) dishonorable discharge.

Sanction toward the notarial deed, which turns into a private deed, is set under Article 16 subsection (9), Article 44 subsection (5), Article 49 subsection (4), Article 50 subsection (5), Article 51 subsection (4), and Article 52 subsection (3); while the violation on the provision of Article 16 subsection (12), Article 50 subsection (5), Article 51 subsection (4), Article 52 subsection (3) provides rights for the injured party to claim for indemnification of any expenses, damages, and interest to the notary.

The notary public should assure that the deed they establish is consistent with the predetermined regulation, thus, the interests of pertinent parties can be assured with the deed. With such legal relationship, it is necessary to determine the position of the legal relationship between the notary and the client as it is the beginning of the notary's liability.

Similarly, the provision for Land Deed Official (later known as PPAT) is set under the government regulation Number 37 of 1998 about the Regulation of Profession for Land Deed Official (later known a PP Number 37 of 1998) subsequently amended by the government regulation Number 24 of 2016 about the Amendment of Government Regulation Number 371998 about Land Deed Official (later known as PP PP 24 of 2016), associated to the government regulation Number 24 of 1997 about the Registration of Land (later known as PP 24 of 1997) and the Regulation of Minister of Agrarian Country/ Head of National Land Body Number 3 of 1997 about the Provision of Implementing Government Regulation Number 24 of 1997 about the Registration of Land (later known as Kepmen Negara Agraria/ Head of BPN Number 3 of 1997). Article 1 Number 1 PP 37 of 1998 mentions that PPAT is a public official authorized to establish an authentic deed of particular legal actions dealing with the freehold or the ownership of apartment units. 
The primary function of PPAT is to implement a part of of land registration activities by establishing a deed as the evidence that particular legal action has completed on the freehold or the ownership of apartment units, and it will become the basis for registering any alteration on land registration data due to the legal action. Such intended legal action, as mentioned in Article 2 subsection (1) PP 37 of 1998, includes: commerce, exchange, grant, inclusion into company (inbreng), shared distribution of rights, the distribution of building rights/rights to use a freehold land, the distribution of assurance, and the authority to assign an assurance.

A liability reveals when a notary public and PPAT has neglected the legal responsibility they are supposed to conduct, or in case, both notary public and PPAT has tort over the claimer as set under Article 1267 Burgerlijk Wetboek (BW), or they have violated particular law (onrechtmatige daad) as mentioned in Article 1365 BW. Thus, the insurance of professional liability for notary public and PPAT acts as a risk transferring of possible compensation for any damages the injured party has suffered from due to the official's violation. The notary public and PPAT may establish an insurance agreement with an insurance company to cover any possible damages suffered by their clients or other parties by establishing a kind of insurance of professional liability. The legal responsibility over the third party refers to the responsibility, based on the liability insurance policy, that should be completed by the insured toward the third party, when the secured risks by the policy make the third party injured. The insurance object of liability is the insured's obligation to pay compensation for damages the third party has suffered from.

\section{B. PROBLEM STATEMENTS}

According to the background previously described, a research problem could be made; does the insurance of liability refer to the attempt of taking over any possible risks due to the fault of a Notary Public and Land Deed Officials? 


\section{RESEARCH METHOD}

This study was a legal research, aiming to seek for solution against particular legal issues by providing a prescription of what was supposed to be. A statute approach was used to address the issue of insurance of professional responsibility by the Notary Public and Land Deed Official.

\section{DISCUSSION ANS RESEARCH RESULT}

\section{Insurance as a Kind of Risk-Transfer Agreement}

Insurance or assurance in Dutch is known as verzekering or assurantie. While in English, it is known as 'insurance' or 'assurance'. In Arabic, it is known as at-ta'min (Huda, 2016).

Following the provision of article 246 Wetboek van Kophandel (WvK), “assurance is an agreement through which the insurer engages themselves to the insured by receiving premium to provide compensation due to any loss, damages, or the loss of expected return possibly suffered by the insured due to an evement".

Article 1 Number 1 of Act Number 40 of 2014 about Insurance (later known as UU insurance) defined insurance as an agreement between two parties, including insurance company and a policy holder, as the basis for the insurance company to receive premium as the reward for: a) providing indemnification for the insured or the policy holder due to any loss, damages, expense, the loss of expected return, or a legal responsibility toward the third party possibly suffered by the insured or the policy holder due to uncertain event; or b). covering any particular payment based on the evenement of the insured or based on the insured's life with the amount of benefit predetermined and/or based on the result of fund management.

Both Article $246 \mathrm{WvK}$ and Article 1 Number 1 of Act Number 40 of 2014 about Insurance show that the insuranc in legal terminology refers to an agreement. An insurance 
agreement offers a guarantee of an uncertainty due to economic loss which people may suffer for uncertain event (Huda, 2016, p.1037-1041).

Risk is a matter which every human may encounter or expect not to happen. Every human has risk for anything they do. Besides, their lives itself contain risks. Following Mehr (1986), there are 5 (five) ways to cope with the risks, including: a). risk avoidance by not doing any activity which brings possible loss, for instance: avoiding any skyscraper construction in earthquake-prone areas; b). risk reduction by limiting possible loss, for instance: providing anti-fire atomizer in offices; c). risk retention by being still with the risk since it may cause loss; d) risk sharing by sharing risks to other parties, such as reinsurance; and e). risk transfer by assigning risks to other parties, such as insurance company.

Evenement assigned to the insurer is the cause of whether loss, demise or defected body of an insurance object. Evenement is the term adopted from the Dutch identified as an uncertain event. Such uncertainty is an event of which insurance is established, it cannot be either certain or expectable. As long as the even causing loss does not exist yet, the danger threating the object of insurance is identified as risk. When the risk ultimately happens, it may turn into evenement; an event causing loss. In this case, the risk as the threat for the insurer turns into the loss which the insurer must cover (Makhdieva, 2017: 160-174).

The risk secured by insurance is likely to be a risk measurable by money or known as material risk. However, although immaterial risk can be secured by insurance, its loss may not be financially measurable (Rastuti, 2011). Such risk is commonly classified into a kind of money-based insurance. Thus, in a money-based insurance (e.g., life insurance, health insurance, education insurance, etc.), the prominent benefit is identified as investment (saving fund). Therefore, the risk over the insurance of loss (such as: wildfire, car loss, damages, etc.) refers to the uncertainty of a possible event which may cause economic loss.

Following Muhammad (2011), the aims of insurance involves: risk transferring, loss covering, compensation, and member welfare. Insurance is one kind of specific agreements set under $\mathrm{WvK}_{\mathrm{v}}$. The specificity of an insurance as agreement is: a) aleatory, that the 
insurer's performance should still depend on an uncertain event; b)) personal, that the loss is personal in nature and not collective; e) adhesion, that the essence of conditions within agreement is almost entirely created by the insurer; and f) good faith, that there is an agreement between parties who have shared information dealing with any pertinent facts and nothing is hiden (Huda, 2018: 80-86).

As an agreement, the term legality in BW is also applied to insurance. As it belongs to a specific agreement, the term of legality for a insurance agreement does not only apply BW but also a specific term set in $\mathrm{WvK}$ as its rule. The term of legality on the agreement is set under Article 1320 BW involving agreement, proficiency (authority to do legal actions), particular object and allowed clause, while the terms in $\mathrm{WvK}_{\mathrm{v}}$ are set under Article 251 WvK about the obligation to inform: agreement, proficiency, particular object, and clause consistent with legal norms. The insured must inform the insurance object to the insurer. This obligation should be completed prior to the establishment of the insurance agreement. If the insured neglects to provide the information, the insurance is considerably null. Following Article $251 \mathrm{WvK}$, any incorrect or falsified information, or any dissimulation acknowledged by the insured about the insurance object may cause the insurance failed (Huda, 2017: 53-60).

Article $255 \mathrm{WvK}$ mentions that an insurance agreement must be established in written and in the form of a deed called policy. Article 19 subsection (1) of the Government Regulation Number 73 of 1992 about the Organization of Insurance Business sets that the policy or any kind of insurance agreements, along with its enclosure as a unity, is not allowed to contain words or sentences which may cause different interpretation dealing with the risk covered by the insurance, the obligation of the insurer and the insured, or which may complicate the insured to claim their rights.

Based on those two provisions, it can be noted that the insurance policy has a function as written evidence stating that an insurance agreement between the insurer and the insured does happen. As a written evidence, the content of the policy must be clear, without containing any words or sentence which may cause different interpretation that 
complicates the insurer and the insured to realize their rights and obligations in implementing the insurance agreement.

The matter of evenement has close relation with compensation. However, every loss due to evenement does not always have to get compensation, as it is only those covered by the insurer and mentioned in the policy or any loss due to an evenement set in the policy, or evenement and loss that reveals due to causal relationship which loss may be covered by the insurer. The criteria of loss covered by the insured are: a) those derived from uncertain events; b) those uncertain events are covered by the insurer; there is a causal relationship between the uncertainty and the loss; and c) based on the principle of equilibrium.

\section{The Insurance of Liability for the Profession of Notary Public and Land Deed Officials in order to Protect the Clients or Other Parties}

The kinds of insurance are classified into insurance of loss, insurance for some amount of money, syaria'ah insurance, and variety insurance (Rastuti, 2011). Variety insurance is insurance for any sort of objects which grows and develops along with the needs of society. Insurance develops to anticipate the rigidity of WvK which solely regulates insurance in narrow context. The enforceability of this variety insurance is likely to be based on Article 246 and $247 \mathrm{WvK}$ providing openness to other insurance beyond WvK.

The types of loss insurance can be classified into: a) insurance of wildfire (Article 287-298 WvK); b). insurance of maritim (Article 246-286, 592-685, 709-721, 744 WvK); c) insurance of motor vehicle; d) insurance of riot; and e) insurance of theft and burglary. Furthermore, the kinds of insurance for loss are classified into: a) life insurance, b) health insurance; c) employee insurance; and d) education insurance.

The types of variety insurance include: a) credit insurance, referring to the protection provided by an insurance company to conventional banks/finance organizations over the risk of failure of the debtors to fully pay the credit facility or cash loan, such as loan for business capital, loans for commerce, and other loans which banks/finance organizations provide; b) deposit insurance through which it secures for economic risks. 
For instance, the depositor may suddenly encounter difficulty to withdraw the funds saved in bank when the due date has come, hence, the depositor may lose their fund or its value may decrease both the main fund and the interest. The source of risk may happen since the bank in which the fund is saved is bankrupted, the director run away, bad credit, political risk, monetary risk, or inflation; c) insurance of export-import is a kind of insurance that provides compensation to the exporter on possible risks of loss since he/she does not get acquittal from the importer or bank establishing letter of credit due to commercial risk and/or political risk; d) insurance of transport is an insurance product which assures any loss due to damages or loss of goods on the process of transporting from the departure to the destination, goods delivery can be through marine cargo, air cargo, or land cargo; and e). Insurance of liability is an insurance product which provides assurance to the insured for any risks emerge due to claim from another party (the third party), and it deals with personal activities, profession, or company that belongs to the insured. This kind of insurance is classified into insurance of loss.

Regarding to the insurance of liability for the profession of Notary Public and Land Deed Official which acts as a risk transferring of any possible claims of injured party due to violation that notary public and PPAT did, the notary public may make an insurance agreement with insurance company in the form of a liability insurance to cover their clients' possible loss.

The legal responsibility toward the third party refers to the obligation the insured must complete toward the third party based on the policy of liability insurance. That is, when the risks secured by the policy cause loss against the third party, the insurer must stand in for the insured. The object of liability insurance is the insured's obligation to pay compensation for damages of their injured clients/the third party. As the consequence, the insured must pay some amount of premiums agreed with the insurer. With this insurance, the insured may feel secured from any threat of possible loss as the insurer may have covered it.

Compensation for the client/the third party includes property damages, bodily injury, financial loss, or consequential loss. 
Liability insurance consists of various products, including: a.general liability that involves: public liability; product liability; and comprehensive general liability; $b$. Professional Liability including: medical Malpractice; professional Indemnity; and director's and officer's liability; c. Employer's Liability and d. Workmen's Compensation.

Liability insurance is set under the Law of Insurance. This regulation is specifically based on a free contract between the insured and the insurer and it is established in the form of a deed called policy. This policy is signed by the insurer and functioned as written evidence that the liability insurance has been made between the insured and the insurer.

The written evidence of insurance agreement that is not set under WvK may apply Article $256 \mathrm{WvK}$ about the requirements of the contents of policy, along with some specific terms of condition agreed by both the insured and the insurer. In addition, the general basis of insurance set under $\mathrm{WvK}$ is applied for the liability insurance as well. An insurance company may construct the form and the content of the insurance policy by considering both general and specific conditions agreed by both parties.

The insured of liability insurance for profession is personal, and the insurer can be limited-liability Company, cooperation, and joint venture. Clients and the third parties in such insurance is personal that points to Notary Public and PPAT.

Both Notary Public and PPAT, as the insured, have particular interests and obligation in implementing their professions. The intended obligation points to the accountability of any fault causing loss against the third party. This risk of liability is transferred to the insurer. In fact, the insurance carrying on the liability for any loss due to the insured's liability toward the third party is highly necessary.

The manifestation of an individual's legal responsibility is in the form of compensation of loss due to particular behavior causing damages against others; it is known as liability. This is related to Private Law and measurable by coin. Thus, it excludes any liability related to Public Law, such as Administrative Law and Common Law. Furthermore, Article 1365 BW sets the issue of lawlessness. Based on this Article, it is a must for people to provide compensation of any loss emerge due to their fault. 
Toward Civil Law, many possible behaviors may make others loss. Thus, the liability to compensate the loss due to the fault of particular profession (in this case, notary public/PPAT) is transferred to the insurer. As previously discussed, particularly to the profession of Notary Public and PPAT, the claim for compensation can be filed based on either tort or lawlessness (onrechmatige daad). Any loss due to the tort or lawlessness by Notary Public and PPAT may belong to those officials and must be fulfilled toward the third party. This obligation to the third party is the object of liability insurance, as it covers a quite big amount and difficult to cope by the Notary self. With insurance contract, Notary Public and PPAT, as the insured, may assign the risk of compensation to the insurance company, as the insurer. That is, the insurer will cover the compensation based on the insurance contract they have made.

In this liability insurance of Notary Public and PPAT, the evenement is in the form of tort or lawlessness. Following the nature of evenement, tort or lawlessness must be unexpected. That is, it is unexpected to happen since the Notary and PPAT, at the insured, realize the consequence; a loss for other parties that needs to have indemnification. Therefore, the Notary and PPAT, as the insured, should be careful and thorough in implementing their profession. However, if such tort remains to happen, the loss due to the fault must be indemnified. Recognizing such possible tort and lawlessness, the Notary Public and PPAT, as the insured, make an insurance to transfer any risks of possible loss to the insurer.

When tort or lawlessness is intended to cause loss against another party (the third party), the insurer has no obligation to provide any indemnification. This is set under Article $276 \mathrm{WvK}$, that the insurer has nothing to do with any loss emerged due to fault the insured intentionally did. Even, the insurer remains entitled to the premiums received.

Premium is a key element of insurance as it is the primary obligation the insured should fulfill toward the insurer. As to Insurance Law, the insurer is assigned for risk transfer by the insured and, thus, the insured has to pay some amount of premium as the reward. If the premium is not paid, the insured may become null or, at least, the insurance may not work. The premium must be paid by the insured since he/she is the one with 
interest. Determining the amount of premium must be based on a fair analytical calculation of risk. The amount of premium that must be paid by the insured is based on a risk appraisal assigned to the insurer. In fact, it is based on the agreement between the insurer and the insured in a proper way and then mentioned on the policy. The amount of premium is calculated in such a way, thus, by receiving premiums from some insured, the insurer is capable to pay their claim for any loss due to the insured's fault.

In Indonesia, the insurance of liability for profession has been applied to the profession of doctor with maximum claim up to IDR 500.000.000 (five hundred million rupiahs). The advantage of profession insurance for doctor is: (a) providing medicolegal and legal assistance for the doctors that receive a claim in order to run the process of seeking for solution dealing with a notion of negligence, and the doctor will be assisted to do the process of legal protection; (b) advocation by a competent, credible, and experienced medicolegal team during the claim; (c) giving the best efforts to improve the awareness of law, ethics, and safe practice for the insured through a medicolegal workshop' (d) the claim for indemnification can be disbursed during pre-trial (with approval from the pertinent doctor and the medicolegal team after having analysis [stratelijk medikolegal]); (e) assuring that any locations of practice correspond to the applied law; (f) professionally assuring the doctor that, in his/her practice, the fault is found commited by particular non-medical staff who works with him/her, and with affordable premium as well.

The content of professional liability insurance policy for Notary Public contains particularly specific conditions such as: (a) the date of insurance establishment; (b) the name of the insured including the name and the area of the notary's function; (c) the possible risks assured should be in a very clear description on its evenements covered by the insurance company as the insurer. That is in the form of a claim for financial indemnification due to a tort or particular actions against the law sued to the client in a deed since the Notary Public has been neglected on his/her profession; a claim for financial indemnification due to any actions against the law that put the third party into a loss condition since the Notary has been neglected on his/her profession; the compensation for expenses such as attorney fee and court procedural fee; (d) the insurance premium; (e) the 
insured amount (the value of warrant); (f) when the evenement start to work and end in case of the insurer's responsibility; (g) the exception for particular events not covered by the insurer (the clause of exenotarion); (h) the cause of expiration of the insurance agreement; (i) the solution of dispute; and (j) the addendum.

Exoneration clause is one of clauses contained in insurance policy. It is identified as either redemption or limitation of liability. In this case, it points to the limitation of the insurer's liability. Although the regulation has determined how broad the insurer's responsibility is, as set in Article 290 and $637 \mathrm{WvK}$, the regulation provides the limitation of the insurer's responsibility as well. This can be seen from Article 249, 276, and 293 WvK. Article 249 set on liabilities of the insured object. Article $276 \mathrm{WvK}$ set on liabilities to stand in for the insured's fault. Article $293 \mathrm{WvK}$ set on the limitation of the liability over the risk weighting. Toward these three articles, the insurer is not responsible to pay any indemnification.

If both insured and insurer want to eliminate the limitation set in those three articles, a specific agreement should be made and clearly mentioned in the policy. Using all-risk clause is insufficient to absolve the insured from any risk set in those three articles in WvK as mentioned above. The exception or limitation which can be applied in professional liability insurance policy of Notary Public and PPAT (the insurance will not be valid) if:

a. The exception on loss is expected/desirable or deliberately done by the notary and PPAT/the insured;

b. The exception on loss due to dishonesty, fraudulence, and criminal behavior done by the notary and PPAT/the insured;

c. The exception on loss due to force majeure;

d. The exception on claim or loss that exists before the insurance contract established;

e. The premium of insurance based on the agreed arrangements is not paid yet.

Several conditions making the insurance agreement end are as follow.

1. Due to required evenement

In insurance context, evenement refers to the condition of an event causing loss, or the required risk has happened. In the context of professional liability insurance of notary 
public, the tort or lawlessness by notary as the insured may make the insurance agreement end and the insurer has to pay indemnification (based on the value of assurance) as the consequence of fulfilling obligation.

2. Since the period of agreement has expired

In the context of insurance, each evenement assured by the insurer does not always emerge, even until the period of insurance expires. When the period of the insurance contract expires without any evenement happened, the insurer's responsibility to cover all possible risk will end as well. However, the agreement contains that the insurer may return some money to the insured if, until the period of insurance expires, there is no evenement happens.

3. Since the insurance is aborted

Article $306 \mathrm{WvK}$ mentions that if the insured individual has found died when the insurance contract is established, the insurance will be aborted although the insured does not know the evenement, unless another specific agreement is made.

Article $307 \mathrm{WvK}$ mentions that if an individual insuring his life dies due to suicide or sentenced to death, the life insurance agreement is considered deviated. Deviation from this rule is possible to happen since most of life insurances are closed by a clause allowing the insurer to conduct his/her performance, in case of suicide and the insured's body, as long as the evenement has happened two years ago before the insurance established.

4. Since the insurance is canceled

Insurance may end due to cancelation before the period expires. Such cancelation may happen since the insured does not continue to pay premium based on the agreement, or at the request of the insured itself.

In addition, WvK sets a void threat if the insurance contract:

a. Contains incorrect/falsified information, or, if the insured does not inform things he/she know and, later, when the insurer sees the fact, it will impact on the insurance agreement itself (article $251 \mathrm{WvK}$ )

b. Contains loss that has existed before the insurance contract is signed (article $269 \mathrm{WvK}$ ) 
c. Contains a provision that the insured, by notification through court, absolves the insurer from any possible liabilities (article $272 \mathrm{WvK}$ )

d. Contains an artifice or fraudulence on the insured (article $282 \mathrm{WvK}$ )

e. Contains an insured object which, based on the regulation, is not allowed to trade, and as to shipment, either domestic or foreign ship used to transport the insured object which, based on the regulation, is not allowed to trade (article 599 Trade Code).

Until December 2017, the number of Notary Public and PPAT in Indonesia has reached more than 15,000 (fifteen thousand) Notary Publics and PPAT. With premium cost starting from IDR 5,000,000 (five million rupiahs) to IDR 7,000,000,000 (seven billion rupiahs), as well as the insurance premium for doctor. Thus, it can be imagined how much profit the insurance company may gain compared to the insurance value they must cover.

Hence, given that the profession of Notary Public always encounters risks, it is expected for the Notary and PPAT to have liability insurance as their assurance for any claim received from the injured party due to their fault or negligence. In addition, insurance companies are suggested to offer liability insurance product to the notary public, given high premium they may possibly gain from that offering. Indeed, the relationship between Notary Public and insurance companies may become mutually beneficial relationship as well as the insurance of medical profession applied in Indonesia.

\section{E. CONCLUSION}

Claims for indemnification, interest, and expense due to tort can be filed since the Notary Public \& PPAT, and the plaintiff have made an agreement between them, and the type of claim for indemnification, interest, and expense due to a tort emerges based on the legal relationship between Notary Public \& PPAT and the plaintiff in accordance to the provision of regulation.

Avoiding risk of claim for indemnification, interest, and expense, the Notary and PPAT may make an agreement with an insurance company in the form of professional liability insurance to cover any loss suffered by the plaintiff or another party. Therefore, insurance businessmen are expected to immediately offer a liability insurance product with to Notary Public and PPAT. With affordable premium from the insurance company and the 
increasing number of Notary Public and PPAT in Indonesia, a mutually beneficial relationship may exist between Notary Public \& PPAT and pertinent insurance companies.

\section{BIBLIOGRAPHY}

\section{Books:}

Adjie, Habib, 2009, Meneropong Khazanah Notaris dan PPAT Indonesia (Looking at the

Treasury of Indonesian Notaries and PPAT ), Citra Aditya Bakti: Bandung.

Huda, M. Khoirul, 2016, Prinsip Iktikad Baik Dalam Perjanjian Asuransi Jiwa (Good Faith Principle in Life Insurance Agreement), FH UII Press: Yogyakarta.

Lotulung, P. Effendi, 1993, Beberapa Sistem Tentang Kontrol Segi Hukum Terhadap Pemerintah - Seri Ke 1: Perbandingan Hukum Administrasi dan Sistem Peradilan Administrasi (Some Systems About Legal Control of Government-Series 1: Comparison of Administrative Law and Administrative Justice System), Citra Aditya: Bandung.

Mehr, R. Irwin, 1986, Fundamental of Insurance, Richard D. Irwin Homewood: Illinois

Muhammad, Abdulkadir, 2011, Hukum Asuransi Indonesia (Indonesian Insurance System), Citra Aditya Bakti, Bandung.

Nico, 2003, Tanggungjawab Notaris Selaku Pejabat Umum (The Responsibility of the Notary as General Officer), Center for Documentation and Studies of Business Law: Yogyakarta.

Rastuti, Tuti, 2011, Aspek Hukum Perjanjian Asuransi (Legal Aspects of Insurance Agreement), Pustaka Yustisia: Yogyakarta.

Thamrin, Husni, 2011, Pembuatan Akta Pertanahan oleh Notaris (Making Land Deed by Notary), LaksBang Pressindo: Yogyakarta.

Tobing, G. H. S. Lumban, 1983, Peraturan Jabatan Notaris (Notary Position Regulation), Erlangga: Jakarta.

\section{Journals:}


Huda, M. Khoirul, 2016, "The Nature of the Contract of Life Insurance Agency after Enactment of the Act Number 40 of 2014 on Insurance," Journal of Advanced Research in Law and Economics, Issue 5(19),1037-104. https://doi.org/10.14505/jarle.

Huda, M. Khoirul, 2017, “On Obligation to Represent and Disclose Material Facts as a Good Faith in Life Insurance Contract," Mediterranean Journal of Social Scinces, 8:4S1: 53-60.

Huda, M. Khoirul et.all. 2018, "The Principle of Good Faith In Life Insurance Contract: A Comparative Study of Indonesia and UK," The Social Sciences, 13(1): 80-86.

Makhdieva, Y. Makhdievna, 2017, "Social Economic Preconditions and Prospects for the Development of Education Insurance in Russia," European Research Studies Journal, Volume XX, Issue 4A: 160-174. 